\title{
Retinoblastoma cT3c TNM Finding v8
}

National Cancer Institute

\section{Source}

National Cancer Institute. Retinoblastoma CT3C TNM Finding v8. NCI Thesaurus. Code C140694.

Raised intraocular pressure with neovascularization and/or buphthalmos. (from AJCC 8th Ed.) 